\title{
Continuous-Discrete Boundary Problems in the Concepts of the Construction of Foundry Rotary-Conveyor Lines Nepārtraukti diskrētas robežproblēmas
} rotējošo-konveijeru līniju konstruēšanas koncepcijās

\author{
Volodymyr Doroshenko ${ }^{1}$, Volodymyr Kravchenko ${ }^{2}$, Olena $\mathrm{Mul}^{3}$, Olena Tokova ${ }^{4}$ \\ ${ }^{1,2}$ Physico-Technological Institute of Metals and Alloys, Kyiv, Ukraine \\ ${ }^{3}$ Ternopil National Ivan Puluj Technical University, Ternopil, Ukraine \\ ${ }^{4}$ International Research and Training Center for Information Technologies and Systems, Kyiv, Ukraine
}

\begin{abstract}
The problem of mathematical construction for the process of the control of the metal casting crystallization and cooling in a foundry mold is considered. The casting is surrounded by a layer of sand mixture, which is a porous dispersed medium that conducts heat, in terms of the concepts of the construction of foundry rotary-conveyor lines (RCL). The problem of developing an interval model for determining the speed of the conveyor line from the production of metal castings is studied. Herewith, continuous processes of the transport and technological movement of the processed materials, equipment, tools, energy carriers, and final production output are combined with inevitable stops of this continuity, which lead to discreteness, and a combination with a number of accompanying continuous, discrete or reciprocating processes. The adequacy of the model for the given technological parameters is justified. The mathematical description and agreement of the values of technological parameters for regulation and finding the optimal speed of the conveyor line at the interaction of its component rotational systems, as well as the mathematical models for program control and remote monitoring of technological modes in order to obtain the casting of the given quality are considered. The possibility of selecting the corrective parameters for the change of the conveyor line speed is shown.
\end{abstract}

Keywords - Continuous-discrete boundary problems, domains of control, foundry rotary-conveyor lines, monitoring, structurally heterogeneous environments.

\section{INTRODUCTION}

In the XXI century, with the acceleration of the pace of scientific and technological progress, the intensity of human labor decreases noticeably, and, at the same time, its productivity increases; therefore, the model and the structure of production change. Within the framework of the new technological paradigm, it becomes digital ("paperless"), more automated and robotized ("unmanned"), non-waste, and more distributed territorially - against the background of growing network interaction in economy and society. Computer engineering technologies provide the creation of models of high degree of conformity with real processes and constructions, instead of expensive full-scale models, which allows reducing production costs significantly.

The implementation of highly efficient equipment by the principle of rotary-conveyor lines (RCL) that correspond to modern trends in productivity increase was not successful in the foundry industry because the design of such lines required new technological processes of shaping foundry models, foundry molds, and metal castings in the processes of pouring, hardening, and cooling of the latter.

The main requirements for such processes include: the regulation of the heat exchange intensity at the boundary "metal-mold" with the minimization of the duration of the castings hardening and obtaining the form, which simultaneously should be equivalent; filling of molds with metal according to the corresponding program, which provides the given speed of the movement of metal in the mold regardless of its cross section, for molds of different geometry and mass. Generally, the regulation of synchronous supply, turnover and utilization of materials, energy carriers, equipment, tools, labor costs, control and security means and functions at the minimum shop area with the equipment of low capital intensity should be ensured.

The analysis of the given conditions regarding high-speed technologies in comparison with the modern foundry technologies for obtaining castings in sand molds allows asserting the following: The types of casting, optimal for adaptation to high-speed technologies, are the types of Lost Foam Casting (LFC) in the process of gravitational pouring of the mold by metal or with the filling of the mold and crystallization of castings under controlled pressure, which were created at the Physico-Technological Institute of Metals and Alloys of the National Academy of Sciences of Ukraine.

When obtaining castings by models, which are exposed to thermodestruction in the foundry mold under the action of the metallic melt flow, the structural transformations of the metal melt into the casting occur as a result of complex processes of heat and mass exchange in the system "model-metal-sand mold" [1]. 
Therefore, when filling the mold with a liquid metal, it is necessary to control optimally the gas pressure equilibrium support on the border of surfaces "model-mold" [2] as well as to carry out the purposeful control of the metal structure formation by the methods of regulated cooling.

\section{STATEMENT OF THE RESEARCH TASK}

Let us consider the problem of cooling and crystallization in the example of a cylindrical casting, surrounded by a layer of a sand mixture, which is a porous dispersed medium that conducts heat. Heat emission occurs through the porous layer, under conditions of the air (gas) flow passing through it.

Herewith, the process of the casting cooling in the system "model-casting-sand mold" determines the formation of the casting from a liquid state in a structurally heterogeneous (continuous-discrete) environment. This follows from the fact that the heat flow from the casting passes through layers of environments with different physicochemical characteristics such as density, heat capacity, coefficients of heat conductivity and heat emission, geometrical parameters of separate particles of dispersed medium, etc. The structuralphase transformations of the metal melt into the casting occur as a result of complex processes of heat and mass exchange in such structurally heterogeneous systems.

The regulation of the heat process in such systems requires the study of the interaction of the system with the gas-dynamic flow, inherent for LFC, with the continuous extraction of thermal energy from the cooled casting.

In mathematical terms, this leads to the study of boundary problems, where the solution of the problem must satisfy not only the differential equation and the boundary conditions but also an additional system of conjugation conditions, imposed on this solution. Such system takes into account the transition of the heat flow from one physical environment to another one with other physical parameters, i. e., to the study of the class of continuous-discrete boundary problems [3]-[4].

Continuously-discrete boundary problems are widely used in dynamical and thermal studies of constructions and separate mechanisms in the aviation, space, shipbuilding, metallurgy industry, etc. In fact, the most of technological systems have continuous-discrete parameters and their research is related to solving continuous-discrete boundary problems. At present, modeling of casting processes is set as a strategic tool for the optimization of the production process and improvement of the product quality.

The study of real technological systems with continuousdiscrete parameters is connected with solving partial differential equations with variable coefficients with an arbitrary finite number of discontinuities on the interval of integration. Solutions of such equations must satisfy not only the boundary conditions but also often complex differential conjugation conditions, which significantly complicates the solving.

Since the methods of the exact analytical solution of partial differential equations with variable coefficients, except special cases, do not exist, this also complicates the task of the dynamical and thermal research of continuous-discrete technological systems.

Therewith, it is necessary to point out the presence of mathematical unity in solving both just discrete and just continuous boundary problems, which can be generalized to exactly continuous-discrete boundary problems.

Taking into account the hyperbolic heat conduction equation [5] and considering the cooling process as a nonstationary one, we approximate the thermophysical state of such control system by the ordinary differential equation of the 2nd order:

$$
x^{\prime \prime}(t)+a_{1}(t) x^{\prime}(t)+a_{2}(t) x(t)=v(t),
$$

where $x(t)$ is the temperature distribution by time; $v(t)$ is the control function.

In this case, we choose that the control parameter is the velocity of the air flow, which passes through the sand layer that conducts heat.

\section{DETERMINATION OF THE CONDITIONS OF THE STABILITY OF THE FOUNDRY SYSTEM THERMOPHYSICAL FIELD}

Let us consider the conditions of the stability and controllability of the considered thermophysical field for foundry systems, described by differential equations with variable coefficients.

Taking into account the differential equation (1), the thermophysical state of the investigated thermal field can be defined in the general form by the system of differential equations:

$$
\frac{d x}{d t}=x(t) A(t),
$$

where $A(t)$ is the matrix of the $n$-th order, the elements $a_{i j}(t)$ of which are the periodic functions with the period $T ; x(t)$ is the vector of phase coordinates of the dimension $n$.

Considering this system as a structurally heterogeneous one [3]-[4], to the system of equations (2) we add the system of additional interrelations, which is the system of conjugation conditions of the following form:

$$
\left[x_{k}(t)\right]_{t=t_{i}}=0
$$

where $k=1,2 ; i=1, \ldots ; t \geq 0$.

Using one of the known numerical methods, we construct the normal fundamental system of solutions $\Phi(t)$ of the equation (2), which is the matrix of the $n$-th order with the elements $\varphi_{i j}(t) \quad . ., i, j=\overline{1, n}$ :

$$
\Phi(t)=\left|\begin{array}{ccc}
\varphi_{11}(t) & \ldots & \varphi_{1 n}(t) \\
\ldots & \ldots & \ldots \\
\varphi_{n 1}(t) & \ldots & \varphi_{n n}(t)
\end{array}\right|
$$

Here, if in all functions $\varphi_{i j}(t)$ to replace $t$ with $t+T$, then, by virtue of the periodicity of the coefficients $a_{i j}(t)$,we again obtain the solution of the equation (2).

The obtained solution will not coincide with the initial one, but, as any solution, it will be a linear combination of the 
functions $\varphi_{i j}(t)$, which form the normal fundamental system of solutions:

$$
\varphi_{i j}(t+T)=\sum_{j=1}^{n} \varphi_{i j}(T) \varphi_{i j}(t), \quad j=\overline{1, n} .
$$

Now, taking into account the above relationship (4), we obtain:

$$
D(\gamma)=\left|\begin{array}{ccc}
\varphi_{11}(T)-\gamma & \ldots & \varphi_{1 n}(T) \\
\ldots & \ldots & \ldots \\
\varphi_{n 1}(T) & \ldots & \varphi_{n n}(T)-\gamma
\end{array}\right|=0
$$

Equation (5) has the $n$-th order relative to the parameter $\gamma$, and it is the characteristic equation for the system of differential equations (1).

If the roots of equation (4) in absolute value are less than one, then the system of equations (2) is asymptotically stable relative to thermal perturbations.

Thus, when forming the cylindrical casting in the sand mold, the exact solving of the problem of obtaining the cast structure with the given properties is related to the accuracy of the mathematical model, which reflects the domains of the control of the casting cooling process.

The presented ways of the research of the domains of the castings cooling process control allow formulating the principles and possible directions of the optimization of the parameters for the control of the quality of cast parts of various functional purposes.

\section{ANALYSIS OF THE CONTROLLABILITY OF THE THERMOPHYSICAL FIELD OF FOUNDRY SYSTEMS}

Let us consider the equation (1) and reduce it to the system of two ordinary differential equations of the first order in the normal form:

$$
\begin{aligned}
& \frac{d x_{1}}{d t}=x_{2}, \\
& \frac{d x_{2}}{d t}=-\sum_{k=1}^{2} a_{k}(t) x_{k}(t)+v(t), \\
& t \in G=(0, \infty) \in R^{1}, G_{i}=\left(t_{i-1}, t_{i}\right) \subset G, \quad t \geq 0 .
\end{aligned}
$$

The solutions of the system of differential equations (6) are the function $x_{l}(t)$, which is the function of the casting temperature change during cooling, and the casting cooling rate, which is determined by the function $x_{2}(t)$.

Considering the system (6) as a structurally heterogeneous one [3]-[4], to the system of equations (6) we add the system of additional interrelations, which is the system of conjugation conditions of the following form:

$$
\left[x_{k}(t)\right]_{t=t_{i}}=0 \text {, }
$$

where $k=1,2 ; i=1, \ldots ; t \geq 0$.

In turn, the solution of the system of equations (6), as a Cauchy problem solution, will be sought under the following initial conditions:

$$
\bar{x}\left(t_{0}\right)=\left[x_{1}\left(t_{0}\right), x_{2}\left(t_{0}\right)\right], t_{0}=0 .
$$

Then, the general solution of the boundary problem (6)-(8) of the regulation for the process of forming the structure by means of the accelerated heat elimination from the casting surface can be written as follows:

$$
\begin{aligned}
& x_{k}^{i}(t)=\sum_{j=1}^{2} u_{j, k}^{(i)} \varphi_{k, j}^{(i)}(t) x_{j}(0)+\psi_{k}^{(i)}(t), \\
& t \in G_{i} \subset G \in R^{1}, k=1,2 ; i=1, \ldots ; t \geq 0,
\end{aligned}
$$

where the coefficients $u_{j, k}^{(i)}$ are determined by the recurrent formulas [4].

In the relationship (9), the vector $\bar{\psi}(t)=\left\{\psi_{1}(t), \psi_{2}(t)\right\}$ is the partial solution of the heterogeneous system of equations (6) at zero initial conditions:

$$
x_{k}^{i}\left(t_{i-1}\right)=0, k=1,2 ; i=1, \ldots ; t=0 .
$$

This solution can be found with the help of the method of the variation of arbitrary constants:

$$
\psi_{k}^{(i)}(t)=\sum_{j=1}^{2} u_{j, k}^{(i)} \varphi_{k, j}^{(i)}(t) \int_{t_{i-1}}^{t_{i}} \frac{\operatorname{det} \Phi_{j}^{i}(\tau)}{\operatorname{det} \Phi^{i}(\tau)} d \tau .
$$

Let us introduce the next notation:

$$
R_{j}(t)=\frac{\operatorname{det} \Phi_{j-1}^{i}(t)}{\operatorname{det} \Phi^{i}(t)} .
$$

Then, taking into account (10), the solution of the original boundary problem (6)-(8) can be written in the following way:

$$
x_{k}^{(i)}(t)=\sum_{j=1}^{2} u_{j, k}^{(i)} \varphi_{k, j}^{(i)}(t)\left[x_{j}(0)+\int_{t_{i-1}}^{t_{i}} R_{j}(\tau) v(\tau) d \tau\right],
$$

where $t \in G_{i} \subset G \in R^{1}, k=1,2 ; i=1, \ldots ; t_{0}=0 ; t \geq 0$.

We will consider the control of the system (6) relative to the origin of the coordinates, i. e., $x_{k}(t)=0, \forall t$.

Taking this into account, from the system of solutions (11) we obtain a homogeneous system of linear algebraic equations relative to the coordinates $x_{j}(0)$.

The obtained homogeneous system of linear algebraic equations, due to the fact that $\varphi_{k, i}^{(i)}(t) \not \equiv 0, \quad$ can have a nontrivial solution only under the condition

$$
x_{j}(0)+\int_{t_{i-1}}^{t_{i}} R_{j}^{(i)}(\tau) v(\tau) d \tau=0
$$

Thus, to determine the phase trajectories of the system of equations (6) under the control $v(t)$, we obtain the following equation:

$$
x_{j}(0)=-\int_{t_{i-1}}^{t_{i}} R_{j}^{(i)}(\tau) v(\tau) d \tau,
$$

where $j=1,2 ; i=1,2, \ldots$. 
Considering this control system, we introduce the limit on the absolute value of the control action, namely on the value of the air flow velocity:

$$
|v(\tau)| \leq V
$$

To determine the domain of control $F$, we use the definition of the supporting hyperplane [6] as a generalized concept of the usual surface of a two-dimensional space for the case of an n-dimensional Euclidean space.

The hyperplane is given by one equation $F\left(x_{1}, \ldots, x_{n}\right)=0$ with coordinates, where $F$ is a differentiated function.

We will also use the concept of the supporting plane.

The supporting plane to some set $M$ at its point $A$ is the plane that passes through the point $A$ so that the set $M$ is entirely on one side of this plane, i. e., in one of the closed half-spaces, defined by this plane.

Supporting planes are of great importance in the study of convex bodies, to which various castings exactly belong.

To construct the domain of control, we take an arbitrary unit vector $\bar{I}=\left\{i_{1}, i_{2}\right\}$ and construct all possible supporting hyperplanes for the domain of control. Because of the closedness and symmetry of the control domain, there are two such hyperplanes [6]: $P(\bar{I}, \bar{T})$ is the plane, for which the unit vector $\bar{I}$ is directed to the half-space that does not contain the control domain, and $P(-\bar{I}, \bar{T})$ is the plane symmetrical to $P(\bar{I}, \bar{T})$. Here $\bar{T}$ is the vector $\bar{T}=\left\{t_{0}, t_{1}, \ldots\right\}$.

Let $d(\bar{I}, \bar{T})$ is the distance from the coordinate origin to supporting planes $P(\bar{I}, \bar{T})$ and $P(-\bar{I}, \bar{T})$ in the sense of the Euclidean metric.

Taking into account the condition of the convexity of the control domain, it will contain those and only those points, coordinates of which satisfy the inequalities $(\bar{I}, \bar{x}(t)) \leq d(\bar{I}, \bar{T})$ for all possible unit vectors $\bar{I}$.

For the distance $d(\bar{I}, \bar{T})$, the next relationship holds:

$$
d(\bar{I}, \bar{T})=\sup _{x \in F}(\bar{I}, \bar{x}(t))=\sup _{x \in F} \sum_{j=1}^{2} \int_{t_{i-1}}^{t_{i}}-R_{j}(\tau) v(\tau) d \tau
$$

Now, taking into account equation (12), we can write the following:

$$
d(\bar{I}, \bar{T})=\int_{0}^{T} v(\tau) \sum_{j=1}^{2}-R_{j}(\tau) i_{j} d \tau .
$$

Maximizing the expression (14) under restriction (13), we obtain the following control:

$$
v(\tau)=V \operatorname{sgn}\left(\sum_{j=1}^{2}-R_{j}(\tau) i_{j}\right) .
$$

The relation (15) enables us to construct the control vector for research of the domain of the control of the cylindrical casting cooling process as the considered structurally heterogeneous technical system.
In order to implement the proposed method of control, it is possible, in principle, to develop and apply the algorithm, analogous to the algorithm of the Group Method of Data Handling (GMDH) [7], which allows taking into account the influence of a number of parameters of the heat transfer process.

Let us consider the technological aspects of the implementation of the vector control principle in the example of the construction of the technical system for the formation of the cylindrical casting in the sand mold.

In our case, we consider the integral object as a system of $n$ interdependent thermal objects with the temperatures $T_{i},(i=1, \ldots, n)$, which exchange nonzero heat flows with each other and with the environment.

The effectiveness of using these models in search of a technical solution depends on many factors, including the introduction of new methods and techniques of the selection of heat flows from the surface of the casting through the sand layer.

The study of control domains and the development of the models of the systems of the cylindrical casting controlled cooling, using an array of the data of the temperature on the surface plane, is of both theoretical and practical interest.

This can be promoted by the newest achievements in the technical field in the development of small-inertial scanners as well as by other technical developments.

\section{SOME PERSPECTIVES OF CONSTRUCTING RCL AS COMPLEX SYSTEMS WITH CONTINUOUS-DISCRETE PROCESSES}

In general, the topic of the mathematical description and formalization of continuous-discrete processes in real complex systems of foundry production at the present stage of the production digitalization requires in-depth consideration.

Such processes especially adequately match the essence of the concepts of foundry RCL, in which one is seeking the achievement of the continuous processes of transport and technological movement of processed materials, equipment, tools, energy carriers, and the final result, i. e., the production output. These continuous processes are combined with inevitable stops of the continuity, which lead to discreteness, and with combination with a number of accompanying continuous, discrete or reciprocating processes, such as, for example, the ones for RCL based on LFC, production and supply of single patterns, regeneration from removal from the mold to return to the operation of the sand filler molding, etc.

The theoretical and technological foundations of synchronization of these processes are stated in the fundamental monograph [8].

However, as for designing RCL, there is a need for the formation of a number of scientific and technological concepts, for example, such as:

1) How, by means of optimal discretization of the operational-structural layout of RCL, to achieve the maximum continuity, which contributes to the greatest productivity and simplification of controllability?

2) How, by means of controlling and strengthening certain discrete indicators, to achieve the maximum productivity of 
the continuous process, or to minimize the workshop area, occupied by a certain production, or to achieve its greatest resource efficiency, environmental safety, etc.?

3) How by the optimization of a separate discrete component to achieve the maximum indicators of the continuous general or the continuous-discrete one?

Also, it is important to choose the most significant and subordinate discrete components from the continuous general with the gradation of the components by significance or hierarchization and synchronization of separate discrete ones.

Herewith, it is necessary to take into account the degree of continuity obstruction and to construct the analytical system of interrelated functions as a "target production-technological framework" with the general, tending to be continuous, with the maximum efficiency factor.

Besides, for the development of the optimal concepts of the RCL construction, it is appropriate to use the achievements of the last decade in the field of computational methods such as evolutionary algorithms, intelligent data analysis, and other methods that have shown the significant success in solving the problem of finding a stable integral structure for the given composition, in particular, of technological and production elements.

This will increase the potential for forecasting the result of synthesizing the capabilities of constructive and producing elements of RCL among all realizable or expedient combinations of elements that have the best combination of properties according to the set production problem, its optimal resource efficiency, and the proper quality of the casting products.

Such non-empirical methods can combine the known evolutionary approach with the application of accurately structured databases of:

1) production foundry model-molding-melting and heat treatment equipment;

2) high-strength foundry alloys;

3) modern methods of constructing castings;

4) the newest methods of making foundry models, sand molds, and model-box equipment;

5) methods and means of the control of foundry systems and processes.

Also, such non-empirical methods can use the principle of "energy filtration" and Pareto optimization, in order to design and conceptually predict with the guarantee at the stage of the sketch project that the RCL constructions ensure the optimal planned indicators and have a high probability of implementation as production complexes in foundry shops.

Here, it is expedient to use the Pareto principle as the basic directive in the analysis of factors of the efficiency of any technological casting parameters and their optimization relative to the obtained results. Therefore, by correctly choosing the minimum of the most important technological parameters and actions, it is possible to obtain a significant part of the planned full result more easily and quickly, while the further improvements are less effective and may be unjustified.
Thus, for example, in the work [9], the Pareto principle is used to assess the effectiveness of the influence of parameters and foundry objects under lost foam casting on the quality of castings and ecology of the environment, as well as the expediency and objectivity of the Pareto law for the theory and practice of foundry production are stated.

\section{CONCLUSION}

This paper describes the ways of research of the control domains for the cooling process of castings from the liquid state of molten metal, as a key process of their structure formation, by means of methods of applied mathematics.

In terms of the development of the concepts for RCL, such approaches allow formulating the principles and possible directions of the optimization of parameters for controlling the quality of cast parts of various functional purposes.

\section{REFERENCES}

[1] O. I. Shynskiy, "The mechanism of formation of the quality of castings, obtained by lost foam casting (in Russian)," Liteinoye Proizvodstvo, vol. 1, pp. 4-7, 1991.

[2] P. V. Rusakov and O. I. Shynskiy, "The parametric model of the casting process and molding of the casting when feeding the melt to the gasified mold under pressure (in Russian)," Metal and Casting of Ukraine, vol. 9-10, pp. 48-51, 2005.

[3] V. P. Kravchenko, "Determination of solutions for an arbitrary number of their conjugations for the system of ordinary differential equations (in Russian)," Reports of the Academy of Sciences of Ukrainian SSR, vol. 6, pp. 512-514, 1972.

[4] V. P. Kravchenko and N. I. Shut, "On one method for solving problems of thermal conductivity for continuous-discrete rod systems (in Russian)," Inzhenerno-Fizicheskii Zhurnal, vol. 70, no. 2, pp. 290-295, 1996.

[5] A. V. Lykov, "Heat conduction theory (in Russian)," Moscow: Vysshaya Shkola, 1967.

[6] A. M. Formalsky, "Controllability and stability of systems with limited resources (in Russian)," Moscow: Nauka, 1974.

[7] A. G. Ivakhnenko, "Inductive method of self-organizing models of complex systems (in Russian),” Kyiv: Naukova Dumka, 1982.

[8] O. I. Ponomarenko, T. V. Lysenko, A. L. Stanovskiy and O. I. Shynskiy, "Control of casting systems and processes (in Russian)," Kharkiv: National Technical University "Kharkiv Polytechnic Institute", 2012.

[9] O. I. Shynskiy, I. A. Shalevskaya and V. O. Shynskiy, "The application of the Pareto principle for assessing the effectiveness of the influence of parameters and foundry objects on the quality of castings when lost foam casting (in Russian)" in Proc. "Casting. Metallurgy. 2018" XIV Intern. Sc. and Practical Conf., pp. 203-204.

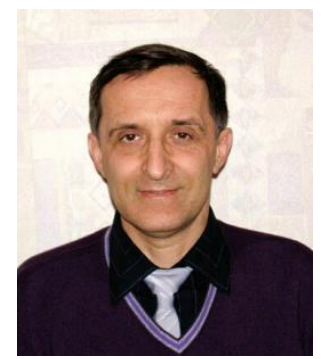

Volodymyr Doroshenko received the Ph.D. degree in technical sciences from Kyiv Polytechnical Institute, Ukraine, in 1990. The theme of the thesis was "Obtaining of Castings of Hydrodistributors from Cast Iron with Globular Graphite in Vacuum-Processed Molds". In 1982, he graduated from Kyiv Polytechnical Institute with the speciality of an engineer in foundry of ferrous and nonferrous metals. He is currently a Senior Research Fellow with the Physico-Technological Institute of

Metals and Alloys, Ukraine.

His major areas of scientific activity are: heat and mass transfer, gas and hydrodynamics of the interaction of a melt and a crystallizing metal with a sand casting mold, physics and chemistry of the processes of sand casting molds production, particularly with the use of vacuumization; new methods of forming for foundry, which ensure an environmental safety of the production and improve the quality of metal castings; methods of casting into vacuumprocessed molds; use of cryo-technologies in foundry, in particular, 
technological bases of the obtaining of accurate blanks by single-use ice models. V. Doroshenko is the author of more than 700 scientific and technical publications, including more than 100 patents for inventions of Ukraine and Russia.

E-mail: doro55v@gmail.com

https://orcid.org/0000-0002-0070-5663

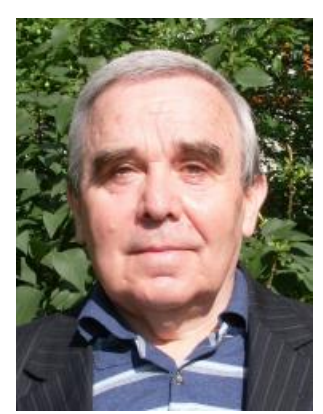

Volodymyr Kravchenko received the Ph.D. degree in physics and mathematics from Kyiv State University named after T. G. Shevchenko, Ukraine, in 1972. The theme of the thesis was "Approximate Methods of Solving Some Boundary Problems in Theory of Elastic Systems Vibrations". In 1964, he graduated from Kyiv State University named after T. G. Shevchenko with a speciality in mathematics. At present, he is a Senior Research Fellow with the Physico-Technological Institute of Metals and Alloys, Ukraine.

His major areas of scientific activity are: investigations of the dynamics and modeling of controlled distributed-discrete systems, continuous-discrete boundary problems for PDE's, continuousdiscrete boundary problems of vibration theory, and normal fundamental systems in problems of vibration theory. He is the author of six scientific monographs and about 300 scientific papers, published in international and Ukrainian scientific journals and presented at international and Ukrainian conferences. From 2002 to 2006, he was the Deputy Director of EngineeringInnovation Committee of Aerospace Society of Ukraine, and a Member of the Committee of Aerospace Society of Ukraine; from 2004 to 2006 - a Member of Ukrainian Academy of Science; and from 1998 to 2002 - a Member of the Scientific and Technical Board of the Cosmonautics Federation of Ukraine. V. Kravchenko has earned the awards of the Cosmonautics Federations of Ukraine and Russia, and the award medals of the Cosmonautics Federation of Russia, named after Yu. Gagarin, S. Korolyov, M. Keldysh, K. Tsyolkovskyj. E-mail: sary942@ukr.net

https://orcid.org/0000-0002-4185-8279

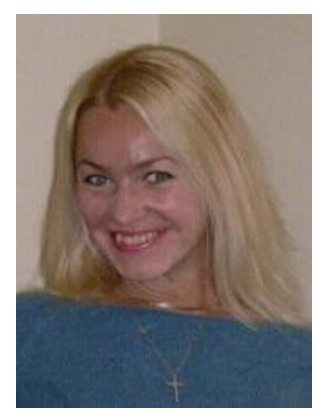

Olena Mul received the Ph.D. degree in physics and mathematics from the Space Research Institute of NASU-NSAU, Kyiv, Ukraine, in 2001. The theme of the thesis was "Analysis of Self-Oscillation Processes in the Complex Continuous and Discrete Systems". In 1994, she graduated from the State University "Lvivs'ka Politekhnica", Lviv, Ukraine, with the speciality of an engineer-mathematician in applied mathematics. She is currently an Associate Professor with the Computer-Integrated Department of Ternopil National Ivan Puluj Technical University, Ukraine.
Her major areas of scientific activity are: control theory on time scales with a special emphasis on hybrid systems; controllability and optimality of nonlinear control systems; analysis and control of dynamical systems; numerical analysis; perturbation theory; theory of vibrations; mathematical physics and computational mathematics for nonlinear boundary value problems in PDE's and ODE's. She is a Member of IAMP, and has received the grants of INTAS, IUPAP, NATO, ESF, UNESCO, CIME, C.I.R.M., the Banach Center (Warsaw, Poland), and Max Planck Institute for the Physics of Complex Systems (Dresden, Germany). She has received a three-year FCT post-doctoral fellowship to carry out a research study "Analysis of Vibrations in Nonlinear Dynamical Systems" at the Department of Mathematics of the University of Aveiro, Portugal, in 2004-2007, and a six-month scientific fellowship to carry out a research study "Numerical and Asymptotical Methods for Highly Oscillatory Differential Equations" at the Department of Applied Mathematics and Theoretical Physics of the Centre for Mathematical Sciences of the University of Cambridge, UK, in 2012.

E-mail: ms.olena@gmail.com

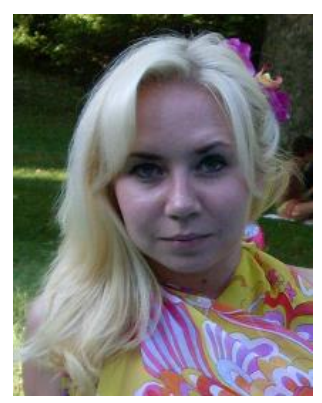

Olena Tokova is a Post-graduate Student at the International Research and Training Center for Information Technologies and Systems of NASU-MESU, Kyiv, Ukraine, from 2012. In 2011, she graduated from the Saint Grand Princess Olha Institute for International Economics, Finance and Information Technology of the Interregional Academy of Personnel Management, Kyiv, Ukraine, with the speciality of a mathematician-programmer in applied mathematics. At present, she is a Software Engineer with Glushkov Institute of Cybernetics of NASU, Ukraine.

Her major areas of scientific activity are: the group method of data handling (GMDH) and other methods of inductive modelling under assumptions; robotics problems on using a mobile robot manipulator for repair and rescue works under extreme conditions of catastrophic situations in underground mining constructions; ecological problems on the development of geoinformation systems for the prediction of natural meteorological disasters; the interval method of telemetry information reliability control for monitoring the casting cooling in a sand mold; mathematical methods for assessing the quality of cast iron by temporal experimental data; monitoring and geoprocessing of the earth surface probing processes. She is the author of more than 20 papers, published in scientific journals and presented at international and Ukrainian scientific conferences.

E-mail: len327@ukr.net

https://orcid.org/0000-0002-0289-2810

\author{
Nepārtraukti diskrētas robežproblēmas rotējošo-konveijeru līniju konstruēšanas koncepcijās \\ Volodymyr Doroshenko ${ }^{1}$, Volodymyr Kravchenko ${ }^{2}$, Olena $\mathrm{Mul}^{3}$, Olena Tokova ${ }^{4}$ \\ ${ }^{1,2}$ Metālu un to sakausējumu fizikāli-tehnoloğiskais institūts, Kijeva, Ukraina \\ ${ }^{3}$ Ternopiles Valsts Ivana Puluja Tehniskā universitāte, Ternopile, Ukraina \\ ${ }^{4}$ Starptautiskais Pētniecības un mācību centrs informācijas tehnologijijām un sistēmām, Kïjeva, Ukraina
}

Tiek skatīta matemātiskās konstrukcijas problēma metāla liešanas kristalizācijas un dzesēšanas kontroles procesam liešanas veidnē. Lējumu ieskauj smilšu maisījuma slānis, kas ir poraini izkliedēts materiāls, kas vada siltumu. Lietojot lietuves rotācijas konveijeru līniju (RCL) koncepciju, tiek pētîta intervāla modẹ̣a izveides problēma konveijera līnijas ātruma noteikšanai metāla lējumu ražošanai. Tajā pašā laikā nepārtraukti apstrādājamo materiālu, iekārtu, rīku, enerğijas nesēju un gala produkcijas transportēšanas un tehnologiskās kustības procesi tiek apvienoti ar šīs nepārtrauktības neizbēgamajiem apstāšanās gadījumiem, kas noved pie kombinācijas ar vairākiem nepārtrauktiem, diskrētiem vai pārvietošanās procesiem. Ir pierādīta modeḷa piemērotība attiecīgajiem tehnoloğiskajiem parametriem. Tiek parādīta iespēja izvēlēties koriǵējošos parametrus konveijera līnijas ātruma maiṇai.

Atslēgas vārdi - Nepārtrauktās-diskrētās robežproblēmas, vadības domēni, liešanas rotācijas konveijeru līnijas, monitorings, strukturāli neviendabīgas vides. 